they may require higher than usual doses of a histamine $\mathrm{H}_{2}$ antagonist, long term omeprazole, or intervention by a surgeon with a special interest in gastric surgery.

ROY POUNDER

Reader in Medicine,

Academic Department of Medicine,

Royal Free Hospital School of Medicine,

London NW3 2QG

1 Chiverton SG, Hunt RH. Medical regimens in short-and long-term ulcer management. Balliere Clin Gastroenterol 1988;ii:655-76.

2 Pounder RE. What is an intractable duodenal ulcer and how should it be managed? Alimentary Pharmacolog $\mathrm{and}$ Therapeutics 1987; 1 ( $\operatorname{suppl} 1): 4395-465$

3 Mignon M, Bonfils S. Diagnosis and treatment of Zollinger-Ellison sỵndrome. Ballieres Clin Gastroenterol 1988;ii:677-98.

4 Bardhan KD. Refractory duodenal ulcer. Gut 1984;25:711-7.

5 Bardhan KD, Naesdal J, Bianchi-Porro G, et al. Treatment of refractory peptic ulcer with omeprazole. Gut 1988;29:A724.

6 Deakin M, Colin-Jones DG, Williams JG. Pharmacological response to cimetidine and healing of duodenal ulceration: effects of high-dose cimetidine and combination of cimetidine with irenzepine. Alimentary Pharmacologv and Therapeutics 1988;2:83-91.

Merki HS, Witzel L, Walt RP, et al. Comparison of ranitidine $300 \mathrm{mg}$ twice daily, $300 \mathrm{mg}$ at nigh and placebo on 24-hour intragastric acidity of duodenal ulcer patients. Alimentary Pharmacology and Therapeutics 1987;1:217-23

8 Lam SK, Lee NW, Koo J, Hui WM, Fok KH, Ng M. Randomised crossover trial of tripotassium dicitrato bismuthate versus high dose cimetidine for duodenal ulcers resistant to standard dose of cimetidine. (jut 1984:25:703-6.

9 Bianchi Porro G, Parente F, Lazzaroni M. Tripotassium dicitrato bismuthate (TDB) versus two different dosages of cimetidine in the treaiment of resistant duodenal ulcers. Gut 1987-28:907-11.

10 Axon ATR. Campylobacter pvlori. In: Pounder RE, ed. Recent advances in gastroenterology-7. Edinburgh: Churchill Livingstone, 1988:225

11 Borsch G, Mai U, Opferkuch W. Oral triple therapy may effectively eradicate Campylobacter pylori in man: a pilot study. (iastroenterology 1988;94:A44.

12 Newmann RD, Gitlin N, Lacayo E, et al. Misoprostol in the treatment of duodenal ulcer refractory to $\mathrm{H}_{2}$-blocker therapy; a placebo controlled multicentre double blind randomised trial. Am $\mathcal{f}$ to $\mathrm{H}_{2}$-blocker therapy; a place

13 Pounder RE. The pharmacological control of gastric acid secretion. In: Pounder RE, ed. Recent advances in gastroenterology-7. Edinburgh: Churchill Livingstone, 1988:245-60.

4 Tytgat GNJ, Lamers CBHW, Hameeteman W, Jansen JMBJ, Wilson JA. Omeprazole in peptic ulcers resistant to histamine $\mathrm{H}_{2}$-receptor antagonists. Alimentary Pharmacology and Therapeutic 1987:1:31-8.

5 Primrose JN, Axon ATR, Johnston D. Highly selective vagotomy and duodenal ulcers that fail to respond to $\mathrm{H}_{2}$ receptor antagonists. Br Med f 1988;296:1031-5.

16 Berstad A, Aadland E, Bjerke $\mathrm{K}$. Cimetidine treatment of recurrent ulcer after proximal gastric vagotomy. Scand f Gastroenterol 1981;16:891-6.

\title{
Loans for medical students
}

\section{May exclude talented but poorer students}

It is not easy to establish a system of financial support for higher education that reconciles the different and sometimes competing needs of students, families, institutions, and the general public. This government's dissatisfaction with the current grant scheme has led to proposals for loans, an idea first considered 30 years ago by the Anderson committee.' The present white paper describes a non-means tested system of loans to "top up" parental and grant contributions, which will be frozen from 1990. In addition, students will no longer be eligible for income support or unemployment and housing benefits.

The motives behind the plans are not exclusively economic: another intention is to undermine the so-called "dependency culture." The paper claims that the scheme will "contribute to their [the students'] economic awareness and self reliance." The current eroded value of grants might already have let students develop such qualities but, in any case, why should students not be partially dependent during their formative years? The loans scheme will not remove all dependency for many students but merely shift it from one financial agent to another.

Medical education is expensive, and, unlike many students in other faculties, medical students do not have lengthy vacations in which to supplement their income. A recent survey of medical undergraduates found that two fifths had overdrafts and four fifths required supplementary or housing benefits. ${ }^{2}$ The prospect of being dependent on loans for five years (or longer for those at, for example, Cambridge, Oxford, and St Andrews) may well serve as a disincentive to study medicine. This will be particularly true for those from lower income groups, and loan schemes in North America and Scandinavia seem to have discouraged less well off students.' Certainly, the current proportion of medical students from less well off backgrounds cannot have depleted the pool of potential talent from that sector of society. Moreover, the fact that many students regard the selection system as biased does not inspire confidence in the appropriateness of the current composition of the medical student population. ${ }^{3+}$ This is not only an issue of equal opportunities but also one of necessity: as the drop in the proportion of 18-21 year olds affects higher education the need to obtain the best students (including graduates) will be even more compelling.

A loan scheme may still exert important and unintended influences on those who are not deterred from pursuing a medical career. Firstly, it may reduce the number of students who choose to do intercalated degrees and limit the range of options available to students for electives. This matters because they are opportunities for students to develop their full potential and extend their otherwise narrow experience. Secondly, career choice may be partly dictated by the wish to pay off loan debts as quickly as possible rather than to fulfil academic and professional aspirations. Some graduates may thus regard general or private practice as more expedient options than, for example, research. Dormant, unfulfilled aspirations may become a subsequent source of frustration. The impact on career choice may be greater on women, who will have to balance even more carefully than at present the needs of family life and career.

The government has justifiably tried to establish a system of financial support that is "responsive to individuals' economic circumstances," and it advocates that "choice . . . should not be inhibited by an obligation to complete repayment of the loan." I doubt, however, if the proposals will either meet these aims or ensure that medicine does not become the province of privileged students. Whatever form of support is introduced (whether it be an adequate non-means tested grant scheme or a tax based loan scheme that is related to the student's income) it must stimulate the recruitment of those who are able and willing to pursue higher education. Financial support for undergraduates is an investment not a favour extended by the government.

Senior Lecturer in Mental Health,

DAVID A ALEXANDER

Medical School,

Aberdeen AB9 2ZD

1 Baker J, ed. Student loans. The costs and consequences. London: National Union of Students, 1985.

2 British Medical Association. Annual report of the Associate Members Group Committee 1986-7. London: BMA, 1987.

3 Alexander DA, Haldane JDH. Medical education: a student perspective. Med Educ 1979;13:336-41. 4 Alexander DA, Haldane JDH. Medical education: the discontinuers' point of view. Med Educ $1980 ; 14: 16-22$. 